\title{
PENGARUH PENERAPAN MODEL PEMBELAJARAN INKUIRI TERBIMBING (GUIDED INQUIRY) BERBANTUAN LEMBAR KERJA SISWA TERHADAP KEMAMPUAN BERPIKIR KREATIF SISWA PADA MATERI KOLOID
}

\author{
Fiza Sulastri ${ }^{1}$ ), Lisa Utami $^{2}$ ) dan Zona Octarya ${ }^{3}$ ) \\ 1) Jurusan Pendidikan Kimia, FTK, UIN SUSKA Riau \\ E-mail : fizasulastri29@gmail.com \\ 2) Jurusan Pendidikan Kimia, FTK, UIN SUSKA Riau \\ E-mail : 1154 lazoelva@yahoo.com \\ 3) Jurusan Pendidikan Kimia, FTK, UIN SUSKA Riau \\ E-mail : zona.octarya@uin-suska.ac.id
}

\begin{abstract}
This research was instigated by the low of students creative thinking ability at State Senior High School 1 Perhentian Raja. This research aimed at knowing the effect of implementing Guided Inquiry learning model with student workbook toward student creative thinking ability on Colloid lesson at State Senior High School 1 Perhentian Raja. It was Quasi Experimental research. Simple Random Sampling technique was used in this research. The samples comprised two classes, the eleventh-grade students of Natural Science 1 that were 33 students as the Control group and the students of Natural Science 2 that were 32 studentsas the Experimental group. The techniques of collecting the data were tests in the form of homogeneity test as the preliminary data, pretest and posttest as the final data, observation, and documentation. The instrument of this research was creative thinking ability test in the form of essay with the indicators of fluency, flexibility, originality, and elaboration. The pretest and posttest data were analyzed by using $t$ test at 5\% significant level. The research findings showed that there was a significant effect of implementing Guided Inquiry learning model with student workbook toward student creative thinking ability on Colloid lesson that $t$ was 4.268 and the score of Sig. (2-tailed) was 0.00. The coefficient of effect was $22 \%$.
\end{abstract}

Keywords: Guided Inquiry Learning Model, Student Workbook Guided Inquiry Based, Creative Thinking Ability, Colloid

\section{PENDAHULUAN}

Pada era reformasi dan komunikasi, Indonesia memerlukan sumber daya manusia yang kreatif dan terampil untuk menghasilkan karya inovatif. Oleh karena itu, kurikulum pendidikan Sekolah Menengah Atas (SMA) menekankan pada bagaimana memfasilitasi belajar siswa untuk berpikir kreatif agar memiliki kompetensi untuk bekerja sama, memahami potensi diri, meningkatkan kinerja dan berkomunikasi secara efektif dalam setiap pemecahan masalah yang dihadapi. Dengan demikian, pembelajaran di Sekolah Menengah Atas tidak hanya bertujuan untuk pemahaman pengetahuan saja, tetapi juga kemampuan untuk memecahkan permasalahan yang kompleks dalam kehidupan [1].

Perlu disadari bahwa selama ini pendidikan formal hanya menekankan perkembangan yang terbatas pada ranah kognitif saja, sedangkan perkembangan pada ranah afektif (sikap dan perasaan) kurang diperhatikan. Terbukti pada pengajaran di sekolah, jarang sekali ada kegiatan yang menuntut pemikiran divergen atau berpikir kreatif sehingga siswa tidak terangsang untuk berpikir, bersikap, dan berperilaku kreatif [2].

Kemampuan berpikir kreatif merupakan salah satu tujuan yang harus dicapai dalam pembelajaran di sekolah. Berpikir kreatif adalah suatu proses berpikir yang menghasilkan bermacam-macam 
kemungkinan ide dan cara secara luas dan beragam. Pada saat menyelesaikan suatu persoalan, apabila menerapkan berpikir kreatif, akan menghasilkan banyak ide yang berguna dalam menemukan penyelesaian. Kreatif berhubungan dengan penemuan sesuatu, mengenai hal yang menghasilkan sesuatu yang baru dengan mengunakan sesuatu yang telah ada [3].

Kimia merupakan ilmu pengetahuan yang identik dengan percobaan atau eksperimen, serta metode-metode ilmiah lainnya yang dapat memberikan pengalaman kepada peserta didik untuk melakukan pengujian hipotesis dengan merancang percobaan melalui pemasangan instrumen, pengambilan, pengolahan, penafsiran data, serta menyampaikan hasil percobaan secara lisan dan tertulis. Mempelajari ilmu kimia, dibutuhkan kemampuan berpikir kreatif siswa. Oleh karena itu maka salah satu tanggung jawab dari guru kimia adalah mengembangkan kemampuan berpikir kreatif siswa [4].

Berdasarkan hasil wawancara yang dilakukan pada guru kimia di Sekolah Menengah Atas Negeri 1 Perhentian Raja diperoleh informasi bahwa kemampuan berpikir kreatif siswa kurang terlatih khususnya pada mata pelajaran kimia. Hal ini disebabkan oleh beberapa permasalahan yaitu Laboratorium tidak difungsikan, sehingga jarang sekali melakukan praktikum yang dapat melatih kemampuan berpikir kreatif siswa dan siswa kurang tertarik dengan pelajaran kimia sehingga kemampuan berpikir kreatif siswa sangat kurang. Hal ini dapat terlihat ketika diberikan suatu pertanyaan hanya beberapa siswa yang menanggapi pertanyaan tersebut. Sedikitnya siswa yang menanggapi pertanyaan dikarenakan kurangnya ragam ide-ide yang muncul, ide-ide yang muncul tersebut sangat erat hubungannya dengan kemampuan berpikir kreatif. Jadi, ketidakmampuan siswa dalam memberikan ide-ide dalam pemecahan masalah menunjukkan masih rendahnya kemampuan berpikir kreatif di kelas tersebut.

Koloid merupakan salah satu materi kimia yang dipelajari di kelas XI IPA. Materi koloid dapat dipahami dan dipelajari dengan mengamati kejadian atau fenomena yang terjadi dalam kehidupan sehari-hari. Hal ini dapat dibuktikan dengan melakukan eksperimen terhadap kejadian atau fenomena tersebut. Melakukan eksperimen sangat erat kaitannya dengan kemampuan berpikir kreatif yang terdiri dari beberapa aspek. Aspek mengamati, siswa mencoba memberikan banyak gagasan atau jawaban terhadap fenomena yang terjadi yang akan melatih kemampuan berpikir lancar, aspek membuat hipotesis dimana siswa mencoba memikirkan berbagai cara untuk menyelesaikan suatu masalah yang akan melatih kemampuan berpikir luwes, aspek merencanakan dan mengadakan penyelidikan dimana siswa selalu mencoba memikirkan cara-cara yang baru, unik dan tidak biasa dilakukan orang lain yang akan melatih kemampuan berpikir asli, aspek menganalisis data dimana siswa selalu mencoba untuk memperkaya atau mengembangkan gagasan yang ada yang akan melatih kemampuan berpikir merinci. Namun banyak siswa yang menganggap bahwa materi koloid tersebut sifatnya hafalan sehingga tidak mendorong siswa untuk berpikir kreatif [5].

Inkuiri terbimbing (guided inquiry) sebagai solusi untuk mendorong kemampuan berpikir kreatif siswa dengan proses pembelajaran yang dimulai dari kegiatan merumuskan masalah, mengajukan hipotesis, mengumpulkan data, menguji hipotesis, serta merumuskan kesimpulan. Jadi dengan serangkaian kegiatan inkuiri dapat melatih siswa mengembangkan kemampuan berpikir kreatif untuk tidak terpaku hanya pada satu jawaban atau cara pemecahan dari masalah yang ditemui, melainkan dengan memunculkan banyak jawaban atau alternatif cara penyelesaian masalah dengan menerapkan kelancaran (fluency), keluwesan (flexibility) dan keaslian (originality) yang menjadi ciri pemikiran kreatif. Selain itu karakteristik mata pelajaran kimia sangat cocok dengan model inkuiri yakni mengajarkan siswa untuk menemukan sendiri suatu konsep dengan penemuan sehingga menjadi pembelajaran yang bermakna. Pada proses pencarian tersebut, siswa dilatih untuk memecahkan masalah yang dihadapi dengan pemikiran kreatif yang dimiliki [6].

Alat bantu pembelajaran yang digunakan dalam model pembelajaran inkuiri terbimbing adalah lembar kerja siswa. Lembar kerja siswa yang digunakan yaitu berbasis inkuiri terbimbing. Lembar kerja siswa berbasis inkuiri terbimbing adalah lembar kegiatan yang disusun dengan harapan siswa mampu menemukan gagasan baru melalui tahapan merumuskan masalah, 
membuat dugaan, merencanakan dan melakukan percobaan, mengumpulkan dan menganalisis hasil percobaan serta membuat kesimpulan. Siswa mencoba menemukan sendiri pemecahan masalah. Guru hanya membimbing dan memberikan arahan-arahan serta instruksi yang berupa pertanyaanpertanyaan sampai pada suatu kesimpulan tentang materi yang diajarkan [7].

\section{METODE PENELITIAN}

Penelitian yang digunakan adalah quasy experiment [8]. Pada kelas eksperimen akan mendapat perlakuan dengan menggunakan penerapan model pembelajaran inkuiri terbimbing (guided inquiry) berbantuan lembar kerja siswa berbasis inkuiri terbimbing sedangkan kelas kontrol diberikan perlakuan dengan menerapkan model pembelajaran inkuiri terbimbing (guided inquiry) berbantuan lembar kerja siswa biasa. Penelitian dilaksanakan di kelas XI IPA Sekolah Menengah Atas Negeri 1 Perhentian Raja, pada minggu ke-4 April semester genap tahun ajaran 2017/2018. Teknik pengambilan sampel yang digunakan adalah Simple Random Sampling yang sebelumnya telah dilakukan uji homogenitas pada semua kelas, dikatakan simple (sederhana) karena pengambilan anggota sampel dan populasi dilakukan secara acak tanpa memperhatikan strata yang ada dalam populasi itu [9].

\begin{tabular}{cccc} 
Tabel 1. & $\begin{array}{c}\text { Desain } \\
\text { Eksperimen [10] }\end{array}$ & $\begin{array}{c}\text { Penelitian } \\
\text { Quasi }\end{array}$ \\
\hline Kelompok & $\begin{array}{c}\text { Pre- } \\
\text { test }\end{array}$ & Perlakuan & $\begin{array}{c}\text { Post- } \\
\text { test }\end{array}$ \\
& & & \\
\hline Eksperimen & $\mathrm{O}_{1}$ & $\mathrm{X}_{1}$ & $\mathrm{O}_{2}$ \\
Kontrol & $\mathrm{O}_{3}$ & $\mathrm{X}_{2}$ & $\mathrm{O}_{4}$ \\
\hline Keterangan & & &
\end{tabular}

\section{Keterangan:}

$\mathrm{O}_{1}$ : Tes awal yang diberikan pada kelas eksperimen

$\mathrm{O}_{2}$ : Tes akhir yang diberikan pada kelas eksperimen

$\mathrm{O}_{3}$ : Tes awal yang diberikan pada kelas kontrol

$\mathrm{O}_{4}$ : Tes akhir yang diberikan pada kelas kontrol

$\mathrm{X}_{1}$ : Perlakuan pada proses pembelajaran dengan menggunakan model inkuiri terbimbing (guided inquiry) berbantuan lembar kerja siswa berbasis inkuiri terbimbing
$\mathrm{X}_{2}$ : Perlakuan pada proses pembelajaran dengan menggunakan model inkuiri terbimbing (guided inquiry) berbantuan lembar kerja siswa biasa

Teknik pengumpulan data menggunakan metode tes dalam bentuk uji homogenitas sebagai data awal, pretest dan posttest sebagai data akhir, observasi dan dokumentasi. Instrumen penelitian yang digunakan adalah tes kemampuan berpikir kreatif berupa soal uraian (essay) dengan indikator kemampuan berpikir kelancaran (fluency), keluwesan (fleksibility), keaslian (originality) dan keterincian (elaboration). Data-data yang diperoleh dalam penelitian ini akan diolah dan dianalisis berdasarkan jenisnya sebagai berikut:

a. Siswa dikatakan tuntas dalam kemampuan berpikir kreatif apabila telah memperoleh nilai $>75$ (tingkat berpikir kreatif kategori kreatif dan sangat kreatif). Hal ini sesuai dengan kriteria tingkat keberhasilan berpikir kreatif dalam nilai, yaitu:

$85-100 \quad$ : Sangat kreatif

$75-84 \quad$ : Kreatif

65-74 : Cukup kreatif

55-64 : Kurang kreatif

30-54 : Sangat kurang kreatif

$0-29$ : Sama sekali kurang kreatif

Adapun untuk menentukan ketuntasan tes hasil belajar ranah kognitif menggunakan rumus berikut:

Keterangan:

$$
\mathrm{KB}=\frac{\mathrm{T}}{T i} \mathrm{X} 100 \%
$$

KB : Ketuntasan belajar

$\mathrm{T}$ : Jumlah skor yang diperoleh siswa

$T i$ : Jumlah skor total

Setiap siswa dikatakan tuntas belajarnya (ketuntasan individu) jika proporsi jawaban benar siswa $\geq 75 \%$ siswa. Adapun untuk mengetahui ketuntasan hasil belajar maupun kemampuan berpikir kreatif siswa secara klasikal menggunakan rumus berikut:

$$
P=\frac{\sum \text { siswa yang belajar tuntas }}{\sum \text { siswa keseluruhan }} \times 100 \%
$$

Kriteria tingkat keberhasilan siswa dalam persentase yaitu:

$75 \%-100 \% \quad$ : Sangat tinggi

$50 \%-74,99 \%$ : Tinggi

$25 \%-49,99 \%$ : Sedang

0\% $-24,99 \%$ : Rendah [11].

Teknis analisis data terdiri dari uji prasyarat dan uji hipotesis. Uji Normalitas digunakan untuk mengetahui apakah sampel 
yang digunakan dalam penelitian berdistribusi normal atau tidak. Sedangkan Uji Homogenitas digunakan untuk mengetahui apakah sampel penelitian ini dari populasi yang homogen atau tidak. Sedangkan Koefisien Determinasi digunakan untuk mengetahui besarnya pengaruh variabel bebas terhadap variabel tidak bebas. Uji Normalitas dilakukan dengan kolmogorof-smirnov menggunakan SPSS 16.0. Sedangkan Uji Homogenitas menggunakan uji Barlet "Box's M". Uji Hipotesis yang digunakan adalah uji t.

\section{HASIL DAN PEMBAHASAN}

Data hasil penelitian ini diperoleh dari hasil penilaian tes kemampuan berpikir kreatif berupa soal essay yang terdiri dari 10 soal dan penelitian ini menggunakan lembar kerja siswa berbasis inkuiri terbimbing pada kelas eksperimen dan lembar kerja siswa biasa pada kelas kontrol dengan menggunakan model yang sama yaitu model pembelajaran inkuiri terbimbing (guided inkuiry). Hasil lembar kerja siswa disajikan pada Gambar 1 sebagai berikut.

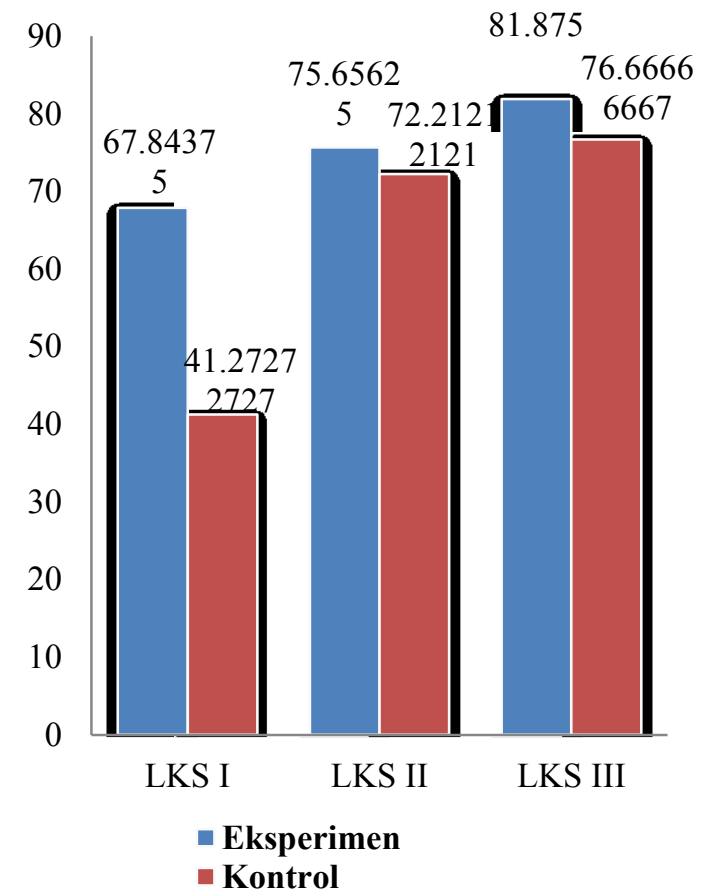

Gambar 1. Diagram Perbandingan Nilai Lembar Kerja Siswa Pada Kelas Eksperimen dan Kontrol

Dari tabel tersebut terlihat bahwa hasil lembar kerja siswa yang didapatkan, dimana siswa mengalami peningkatan pada setiap pertemuan baik itu pada kelas kontrol maupun eksperimen. Namun, rata-rata pada kelas eksperimen (lembar kerja siswa berbasis inkuiri terbimbing) lebih besar daripada kelas kontrol (lembar kerja siswa biasa). Hal ini disebabkan karena pada lembar kerja kerja siswa berbasis inkuiri terbimbing memiliki langkah kerja yang berurutan dan teratur sehingga memudahkan siswa untuk memahami materi dan melaksanakan praktikum. Kegiatan siswa pada setiap pertemuannya yaitu siswa melakukan diskusi dengan sesama kelompoknya dalam melaksanakan percobaan dan mengerjakan latihan pada lembar kerja siswa yang tersedia.

Keterlibatan langsung setiap siswa dan interaksi yang baik antara siswa tersebut dalam menemukan informasi menjadikan siswa tersebut lebih mudah memahami materi sehingga hasil yang diperoleh siswa menjadi lebih baik. Peningkatan yang ditimbulkan dengan penerapan model pembelajaran inkuiri terbimbing (guided inquiry) berbantuan lembar kerja siswa yang juga berbasis inkuiri terbimbing ini menyatakan penelitian yang peneliti lakukan memberikan pengaruh positif, dapat dilihat dari rata-rata hasil latihan yang terdapat pada lembar kerja siswa tersebut. Hal ini selaras dengan penelitian oleh Iryani, menyatakan bahwa hasil belajar siswa yang menggunakan lembar kerja siswa berbasis inkuiri terbimbing lebih tinggi secara signifikan dibandingkan hasil belajar siswa yang menggunakan lembar kerja siswa biasa [12]. Peningkatan hasil lembar kerja siswa pada kelas kontrol dan eksperimen yang terjadi juga sesuai dengan fungsi lembar kerja siswa sebagai acuan untuk memandu pelaksanaan kegiatan pembelajaran dan juga sebagai alat penilaian proses dalam pembelajaran serta sebagai sarana untuk membantu dan mempermudah dalam kegiatan belajar mengajar [13].

Tabel.2 Perbandingan Nilai Pretest dan Posttest Kelas Kontrol dan Eksperimen

\begin{tabular}{ccc}
\hline Kelas & Pretest & Posttest \\
\hline Eksperimen & 44,4063 & 77,5 \\
Kontrol & 49,5152 & 72,4545 \\
\hline
\end{tabular}

Nilai rata-rata posttest masing-masing kelas mengalami peningkatan dari pretest karena siswa sudah mempelajari materi yang terkait yaitu koloid dengan menggunakan 
model pembelajaran. Perbandingan nilai pretest dan posttest kelas kontrol dan eksperimen dapat dilihat pada grafik berikut:

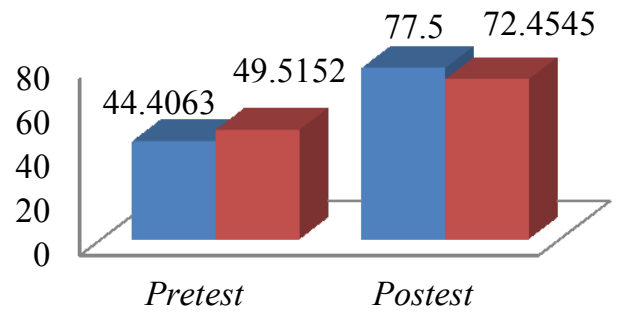

Eksperimen $\quad$ Kontrol

Gambar 2. Diagram Perbandingan Nilai Lembar Kerja Siswa Pada Kelas Eksperimen dan Kontrol

Soal yang digunakan adalah soal yang mewakili indikator kemampuan berpikir kreatif terdiri atas kemampuan berpikir lancar (fluency), kemampuan berpikir luwes (flexibility), kemampuan berpikir asli (originality), kemampuan berpikir rinci (elaboration). Penelitian yang telah dilakukan ini dapat membuktikan bahwa pembelajaran dengan menggunakan model pembelajaran inkuiri terbimbing (guided inquiry) berbantuan lembar kerja siswa berbasis inkuiri terbimbing pada materi koloid berpengaruh terhadap hasil belajar siswa. Hasil belajar yang merupakan hal yang tidak dapat dipisahkan dari kegiatan belajar karena kegiatan belajar merupakan proses sedangkan hasil belajar merupakan hasil yang diperoleh dari proses belajar. Hal ini selaras dengan penelitian Sumarni, Bimo Budi Santoso dan Achmad Rante Suparman, menyatakan penggunaan model pembelajaran inkuiri terbimbing secara signifikan memberikan pengaruh terhadap hasil belajar kognitif siswa[14]. Hal ini juga disebabkan karena serangkaian langkah-langkah kegiatan yang digunakan pada model pembelajaran inkuiri terbimbing (guided inquiry).

Langkah yang pertama yaitu penyajian masalah. Pada tahap ini guru membimbing siswa untuk mengidentifikasi masalah dari suatu fenomena yang diberikan sesuai dengan percobaan yang dilakukan pada setiap pertemuan. Langkah yang kedua yaitu merumuskan hipotesis. Pada tahap ini guru memberikan kesempatan kepada siswa dalam menentukan hipotesis yang relevan dengan permasalahan dan memprioritaskan hipotesis mana yang menjadi prioritas penyelidikan. Langkah yang ketiga yaitu merancang percobaan. Pada tahap ini guru membimbing siswa merancang percobaan sesuai dengan tujuan percobaan dan peralatan yang tersedia. Langkah yang ke-empat yaitu melakukan percobaan. Pada tahap ini guru membimbing siswa melakukan percobaan berpanduan dengan lembar kerja siswa yang telah dibagikan kepada masing-masing kelompok, dimana siswa dalam satu kelasnya terdiri dari 6 kelompok. Langkah yang ke-lima yaitu mengumpulkan data dan menganalisa data. Pada tahap ini guru membimbing siswa mendapatkan informasi atau data-data melalui percobaan yang dilakukan oleh siswa maupun telaah literatur dan membimbing siswa untuk menggali serta mengumpulkan informasi dari berbagai sumber, setelah percobaan selesai maka setiap kelompok diminta untuk mengumpulkan data yang mereka peroleh dari hasil percobaan masingmasing. Kemudian setelah data diperoleh maka siswa diminta untuk membandingkannya dengan literatur yang ada. Langkah yang ke-enam yaitu membuat kesimpulan. Pada tahap ini guru membimbing siswa membuat kesimpulan berdasarkan informasi dan hasil analisis data yang didapatkan untuk menemukan jawaban dari permasalahan yang ada.

Tes " $t$ " merupakan salah satu tes statistik yang dipergunakan untuk menguji kebenaran atau kepalsuan hipotesis nihil yang menyatakan bahwa diantara dua buah mean sampel yang diambil secara random dari populasi yang sama, tidak terdapat perbedaan yang signifikan..Hipotesis dalam penelitian ini diuji dengan uji tes $t$ menggunakan SPSS Versi 16.0 diperoleh nilai t sebesar 4,268 dengan nilai Sig. (2tailed) 0,00. Jika probabilitas $>0,05$ maka hipotesis nihil diterima dan jika probabilitas $<0,05$ maka hipotesis nihil ditolak. Pada nilai Sig. (2-tailed) diperoleh 0,00 yang berarti lebih kecil dari 0,05 maka berarti $\mathrm{H}_{0}$ ditolak dan $\mathrm{H}_{\mathrm{a}}$ diterima. Dengan demikian dapat disimpulkan terdapat perbedaan signifikan penggunaan model pembelajaran inkuiri terbimbing (guided inquiry) berbantuan lembar kerja siswa berbasis inkuiri terhadap kemampuan berpikir kreatif siswa pada materi koloid. Kemudian besarnya pengaruh yang didapatkan dapat dilihat setelah analisis menggunakan koefisien determinasi dengan pengaruh sebesar 22\%. Sehingga ini dapat membuktikan bahwa ada pengaruh penerapan 
model pembelajaran inkuiri terbimbing (guided inquiry) berbantuan lembar kerja siswa berbasis inkuiri terhadap kemampuan berpikir kreatif siswa pada materi koloid.

Model pembelajaran inkuiri terbimbing (guided inquiry) berbantuan lembar kerja siswa dapat membantu siswa berpikir kreatif dan menemukan solusi kreatif dari suatu permasalahan karena melalui model pembelajaran inkuiri terbimbing ini siswa belajar melalui kegiatan pembuktian topik atau isu dengan melakukan kegiatan penyelidikan dan aspek-aspek pada berpikir kreatif dapat ditingkatkan melalui tahaptahap model pembelajaran inkuiri terbimbing. Hasil kemampuan berpikir kreatif siswa dapat di lihat pada gambar 3 dan 4 sebagai berikut:

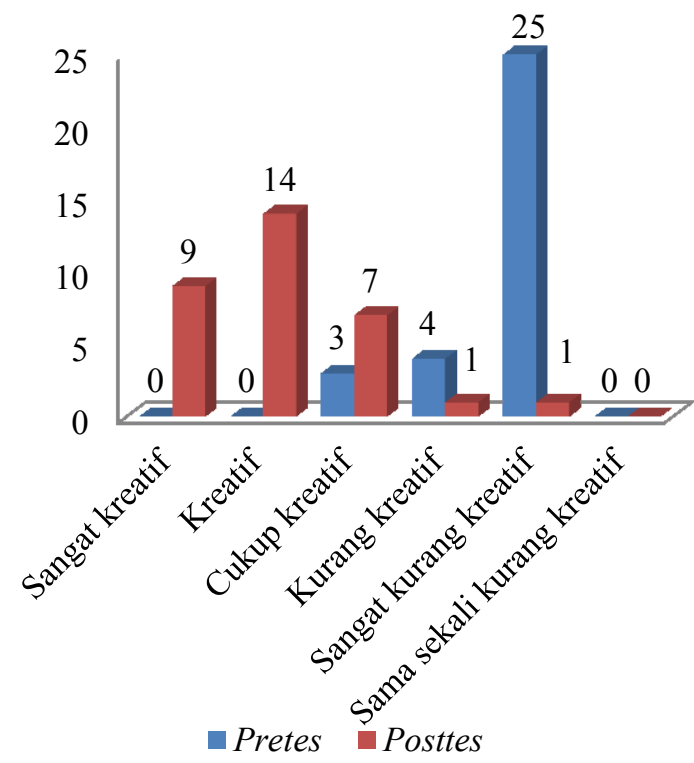

Gambar 3. Diagram Hasil Kemampuan Berpikir Kreatif Kelas Eksperimen

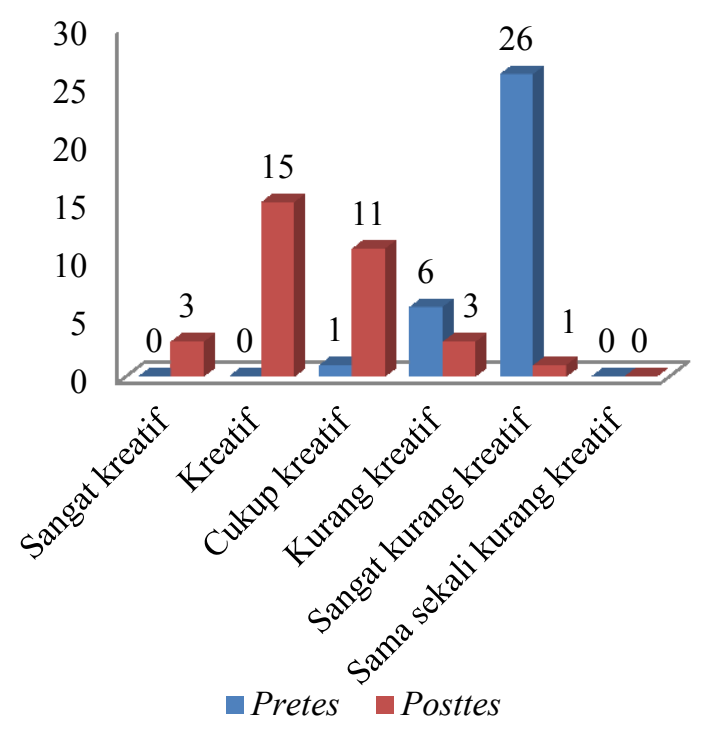

Gambar 4. Diagram
$\begin{gathered}\text { Berpikir } \\ \text { Kontrol }\end{gathered}$

Pada kelas eksperimen setelah diberikan model pembelajaran inkuiri terbimbing (guided inquiry) berbantuan lembar kerja siswa berbasis inkuiri terbimbing diperoleh kemampuan berpikir kreatif siswa sebesar $71,87 \%$ dengan kriteria tinggi sedangkan pada kelas kontrol setelah diberikan perlakuan dengan model pembelajaran inkuiri terbimbing (guided inquiry) berbantuan lembar kerja siswa biasa kemampuan berpikir kreatif siswa diperoleh sebesar 54,54\% dengan kriteria tinggi. Peningkatan penggunaan lembar kerja siswa berbasis inkuiri terbimbing daripada lembar kerja siswa biasa adalah sebesar $17,33 \%$.

54.54

71.87

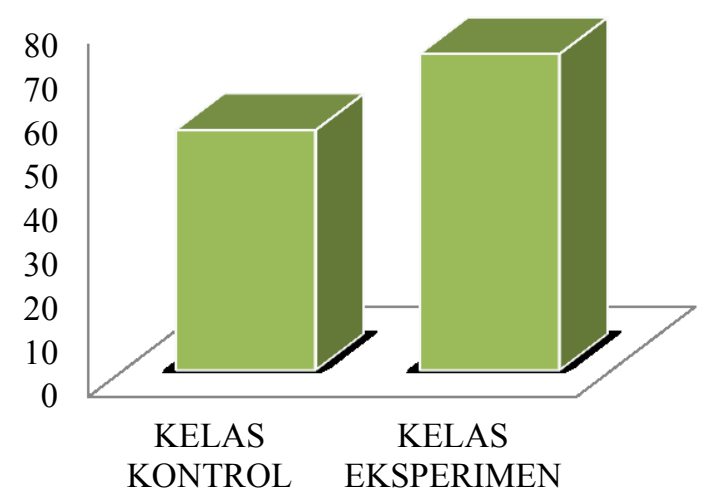

Gambar 5. Perbandingan Nilai Rata-rata Kemampuan Berpikir Kreatif Kelas Kontrol dan Kelas Eksperimen 
Jadi, berdasarkan hasil analisis yang diperoleh dapat disimpulkan bahwa pembelajaran pada kelas eksperimen yang diterapkan model pembelajaran inkuiri terbimbing (guided inquiry) berbantuan lembar kerja siswa berbasis inkuiri terbimbing di Sekolah Menengah Atas Negeri 1 Perhentian Raja pada materi koloid memperoleh kemampuan berpikir kreatif yang lebih baik daripada pembelajaran yang diterapkan dengan model pembelajaran inkuiri terbimbing (guided inquiry) berbantuan lembar kerja siswa biasa.

Kemampuan berpikir kreatif siswa dilatih melalui kegiatan model pembelajaran inkuiri terbimbing. Penerapan model inkuiri terbimbing dapat melatih aspek berpikir luwes (flexibility) pada tahapan membangun hipotesis atas rumusan masalah. Fitri dan Septifiana menyatakan bahwa tingginya kemampuan flexibility peserta didik salah satunya dicirikan dengan kemampuan siswa dalam memikirkan berbagai macam cara untuk menyelesaikan suatu masalah [15].

Apsek berpikir orisinal (originality) mampu ditingkatkan pada model inkuiri terbimbing melalui tahapan merencanakan dan mengadakan penyelidikan. Hal ini disebabkan karena pada tahap ini siswa selalu mencoba memikirkan cara-cara yang baru, unik, dan tidak biasa dilakukan oleh orang lain dalam melakukan penyelidikan untuk membuktikan hipotesis yang sebelumnya telah dibuat. Menurut Munandar berpikir orisinal (originality) menyebabkan seseorang mampu melahirkan ungkapan-ungkapan yang baru dan unik atau mampu menemukan kombinasi-kombinasi yang tidak biasa dari unsur-unsur yang biasa.

Apsek berpikir memerinci (elaboration) mampu ditingkatkan pada model inkuiri terbimbing melalui tahapan merencanakan dan mengadakan penyelidikan dan analisis data. Hal ini disebabkan karena pada tahap ini siswa selalu mencoba untuk memperkaya atau mengembangkan gagasan yang ada serta menganalisis data yang lebih detail dari data yang sudah ada. Menurut Munandar mengatakan bahwa berpikir memerinci (elaboration) menyebabkan seseorang mampu memperkaya dan mengembangkan suatu gagasan yang sudah ada. Siswono juga mengatakan jika aspek kemampuan berpikir kreatif diberi bobot nilai, maka aspek elaboration menempati posisi tertinggi, karena pada aspek elaboration siswa selalu mencoba mengembangkan suatu gagasan atau produk dari yang sudah ada dan berusaha untuk menambahkan atau bahkan memerinci lebih detail dalam rangka untuk menjadi lebih menarik dari sebelumnya. Aspek originality menempati posisi tertinggi berikutnyan karena merupakan ciri utama dalam menilai suatu produk pemikiran kreatif, yaitu harus berbeda dengan sebelumnya dan sesuai dengan permintaan tugas.

Aspek flexibility ditempatkan sebagai posisi penting berikutnya karena menunjukkan pada produktivitas ide (banyaknya ide-ide) yang digunakan untuk menyelesikan suatu tugas. Aspek fluency menempati posisi paling rendah karena pada aspek ini lebih menunjukkan pada kelancaran siswa dalam memproduksi ide yang berbeda dan sesuai permintaan tugas [16]. Kemampuan berpikir kreatif siswa didukung dengan observasi kegiatan siswa pada saat pembelajaran yang dilakukan oleh observer yang terdiri dari empat orang observer. Jadi, urutan kemampuan berpikir kreatif siswa dari yang tertinggi hingga rendah yaitu dimulai dari aspek elaboration - originality flexibility - fluency.

\section{SIMPULAN}

Berdasarkan hasil penelitian ini dapat disimpulkan bahwa terdapat pengaruh signifikan penerapan model pembelajaran inkuiri terbimbing (guided inquiry) berbantuan lembar kerja siswa berbasis inkuiri terbimbing terhadap kemampuan berpikir kreatif siswa pada materi koloid dengan $\mathrm{t}$ sebesar 4,268 dan nilai Sig. (2-tailed) 0,00 dengan koefisien pengaruh sebesar $22 \%$.

\section{REFERENSI}

[1] Marike Muskitta dan Djukri, Pengaruh Model PBT Terhadap Kemampuan Berpikir Kritis dan Kemampuan Berpikir Kreatif Siswa SMA, Jurnal Inovasi Pendidikan IPA, 2016.

[2] Supardi, Peran Berpikir Kreatif dalam Proses Pembelajaran Matematika. Jurnal Formatif, ISSN: 2088-351X. 2015.

[3] Tomi Tridaya Putra, Irwan dan Dodi Vionanda, Meningkatkan Kemampuan Berpikir Kreatif Siswa dengan 
Pembelajaran Berbasis Masalah, Jurnal Pendidikan Matematika, Vol. 1, No. 1 , 2012.

[4] Dewi Satria Ahmar, Hubungan Antara Regulasi Diri dengan Kemampuan Berpikir Kreatif dalam Kimia Peserta Didik Kelas XI IPA Sekabupaten Takalar, Jurnal Sainsmat, Vol. V, No. 1, ISSN: 2086-6755, 2016.

[5] Rusmina Wati, Rusmansyah dan Arif Sholahuddin, Meningatkan Kemampuan Berpikir Kritis dan Hasil Belajar Siswa Kelas XI IPA 2 SMA PGRI Banjarmasin Pada Konsep Sistem Koloid Melalui Model Problem Based Learning, Jurnal Inovasi Pendidikan Sains, Vol. 5, No. 2, 2014.

[6] Anggita Meidy Santika, Diah Gusrayani dan Asep Kurnia Jayadinata, Penerapan Model Pembelajaran Learing Cycle Terhadap Kemampuan Berpikir Kreatif Siswa Pada Materi Perubahan Lingkungan, Jurnal Pena Ilmiah, Vol. 1, No. 1, 2016.

[7] Astuti. Y dan B. Setiawan, Pengembangan Lembar Kerja Siswa (LKS) Berbasis Pendekatan Inkuiri Terbimbing dalam Pembelajaran Kooperatif Pada Materi Kalor, Jurnal Pendidikan IPA Indonesia, 2013.

[8] Aulia Radif, Purnomo dan Siswanto, Pengaruh Penggunaan Model Pembelajaran Inkuiri dan Model Creative Problem Solving (CPS) Terhadap Hasil Belajar Kognitif dan Kemampuan Berpikir Kreatif Mata Pelajaran Mekanika Teknik Siswa Kelas X SMK, Jurnal Teknik Mesin, No. 1, 2016.

[9] Amri Darwis, Metode Penelitian Pendidikan Islam, Pekanbaru: Suska Pers, 2015.

[10] Emzir, Metodologi Penelitian Pendidikan Kuantitatif dan Kualitatif, Jakarta: Raja Wali Pers, 2015.

[11] Isti Dwi Sofiatun Nisa' dan Suryanti, Peningkatan Kemampuan Berpikir Kreatif Siswa melalui Model Pembelajaran Inkuiri pada Mata Pelajaran Ilmu Pengetahuan Alam, Jurnal Pendidikan Guru, Sekolah Dasar. Vol. 01. No. 02, 2013.

[12] Hanni Dwiputri, Nina Kadaritna dan Sunyon, LKS Inkuiri Terbimbing Mempengaruhi Peningkatan Keterampilan Mengidentifikasi Variabel dan Menentukan Langkah Kerja, Jurnal Pendidikan dan Pembelajaran Kimia, Vol. 6, No.3, 2017.

[13] Abdurrohim, Tonih Feronika dan Evi Sapinatul Bahriah, Pengembangan Lembar Kegiatan Siswa (LKS) Berbasis Inkuiri Terbimbing Pada Materi Hidrolisis Garam, Jurnal Penelitian dan Pembelajaran IPA. Vol. 2. No. 2, 2016.

[14] Sumarni, Bimo Budi Santoso dan Achmad Rante Suparman, Pengaruh Model Pembelajaran Inkuiri Terbimbing Terhadap Hasil Belajar Kognitif Peserta Didik di SMA Negeri 01 Manokwari (Studi Pada Pokok Bahasan Kelarutan dan Hasil Kali Kelarutan), Jurnal Nalar Pendidikan, ISSN: 2339-0749, Vol. 5, No. 1, 2017.

[15] Winda Agustina dan Fahriza Noor, Hubungan Hasil Belajar dan Tingkat Berpikir Kreatif Siswa dalam Pembelajaran Matematika, Jurnal Pendidikan Matematika, ISSN 2442304, Vol.2, No.3, 2006.

[16] Redza Dwi Putra, Yudi Rinanto, Sri Dwiastuti, dan Irwan Irfa'i, Peningkatan Kemampuan Berpikir Kreatif Siswa melalui Model Pembelajaran Inkuiri Terbimbing pada Siswa Kelas XI MIA 1 SMA Negeri Colomadu Karanganyar Tahun Pelajaran 2015/2016, Proceeding Biology Education Conference, ISSN: 2528-5742, Vol. 13 (1), 2016. 